\title{
Proses Berpikir Siswa dalam Menyelesaikan Masalah Matematika Berdasarkan Teori Pemrosesan Informasi
}

\author{
Kusaeri $^{1}$, Siti Lailiyah², Yuni Arrifadah ${ }^{3}$, Ni'matul Hidayati ${ }^{4}$ \\ 1,2,3,4 Jurusan Pendidikan Matematika dan IPA, UIN Sunan Ampel Surabaya \\ e-mail: kusaeri@uinsby.ac.id
}

\begin{abstract}
ABSTRAK. Penelitian ini bertujuan untuk mendeskripsikan proses berpikir siswa dalam menyelesaikan masalah matematika berdasarkan teori pemrosesan informasi. Penelitian ini merupakan penelitian deskriptif dengan menggunakan pendekatan kualitatif. Penelitian dilaksanakan di salah satu SMAN favorit di kota Surabaya kelas XIMIA-4. Subjek penelitian dipilih berdasarkan skor Tes Kemampuan Matematika (TKM) dan masukan dari guru bidang studi matematika. Subjek dalam penelitian ini terdiri dari masing-masing dua siswa yang berkemampuan matematika tinggi, sedang, dan rendah. Hasil penelitian menunjukkan bahwa semua siswa menerima informasi atau stimulus berupa soal matematika melalui sensory register dengan indra penglihatan dan pendengaran. Kemudian terjadi attention setelah siswa membaca soal dan muncul perception saat memahami soal. Perception terjadi ketika siswa melakukan retrieval konsep yang dibutuhkan dari long term memory untuk menyelesaikan masalah. Perbedaan saat melakukan retrieval pada masing-masing siswa yaitu siswa yang berkemampuan matematika tinggi mengalami lupa atau forgotten lost terhadap suatu konsep tertentu. Sedangkan siswa yang berkemampuan matematika sedang mengalami kesalahan atau retrieval failure dalam menjelaskan konsep terkait pengertian sudut elevasi. Sedangkan bagi siswa yang berkemampuan matematika rendah sering mengalami kesalahan dan lupa dikarenakan konsep-konsep yang dibutuhkan di short term memory tidak tersimpan dengan baik oleh long term memory.
\end{abstract}

Keywords : Proses Berpikir, Masalah Matematika, Teori Pemrosesan Informasi

\begin{abstract}
This study aims to describe the thinking process of students in mathematic's problem solving based on information processing theory. This research is a descriptive research with qualitative approach. This research was conducted at favorite SMAN Surabaya class XI-MIA 4.Subjects were selected based on the Mathematics Ability Test (TKM) score and interviews with teachers of mathematics studies. Subjects in this study consisted of two students with high, medium, and low math skills. The results showed that all students' receiving the information or stimulus in the form of problems by the sensory registers through the sense of sight and hearing.Then attention occurs after reading the problem and arise perception when understanding the problem. Perception occurs when the students doing the retrieval the required concepts from long term memory to solve the problem. The different doing retrieval in each students are students with high math skills experience forgotten lost to a particular concept. While for students who are capable of moderate mathematics often suffer an error or retrieval failure in explaining the concept related to the meaning of the elevation angle.Then for students with low math skills often experience errors and forget because the concepts needed short term memory is not stored well by long term memory.
\end{abstract}

Keywords: thinking process, mathematics problem, processing information theory

\section{PENDAHULUAN}

Pada hakikatnya, kemampuan berpikir dapat berkembang dengan berbagai materi yang ada di matematika (Rohana, 2015; Khan, 2015; Nayazik dan Sukestiyarno, 2012; Ernest, 2004). Selain 
itu, kemampuan berpikir siswa juga dapat dikembangkan melalui aktivitas belajar. Aktivitas yang dilakukan siswa dalam belajar tersebut tidak hanya dengan mendengarkan materi, menuliskan materi, dan mengerjakan tugas saja, tetapi juga melibatkan proses mental yang terjadi dalam otak, sehingga belajar merupakan aktivitas yang selalu terkait dengan proses berpikir atau proses kognitif (Ngilawajan, 2013; Haji, 2013; Van De Walle, 2008; Panjaitan, 2013). Aktivitas belajar pada matematika tidak cukup hanya dengan menghafal tetapi dibutuhkan adanya proses berpikir, hal ini dikarenakan objek kajian dasar matematika yang berupa fakta, konsep, relasi atau operasi, dan prinsip (Soedjadi, 2000; Mitchelmore\& White, 2004).

Proses berpikir merupakan suatu proses yang dimulai dari menerima data atau informasi, mengolah dan menyimpannya dalam ingatan, yang selanjutnya diambil kembali dari ingatan ketika dibutuhkan untuk pengolahan selanjutnya (Slavin, 2009; Jorczak, 2011). Proses berpikir menurut Ruggiero (2011) adalah suatu aktivitas mental yang digunakan untuk membantu merumuskan atau menyelesaikan masalah, membuat keputusan, dan mendapatkan pemahaman. Sementara Lailiyah (2015) juga mengatakan bahwa berpikir adalah suatu aktivitas mental yang terjadi secara internal dalam melakukan pengambilan keputusan. Dengan demikian, proses berpikir dapat diartikan sebagai aktivitas yang terjadi secara internal dalam otak manusia, sehingga untuk mengetahui bagaimana langkah berpikir siswa dalam menyelesaikan masalah diperlukan sesuatu yang dapat merangsang proses berpikir siswa.

Salah satu cara untuk merangsang proses berpikir siswa adalah dengan memberikan siswa sebuah permasalahan matematika. Ketika siswa menyelesaikan masalah matematika, maka siswa akan berpikir dan berusaha mencari solusi dari permasalahan tersebut. Hal ini sejalan dengan pendapat Solso (2008) yang menyatakan bahwa seseorang akan berpikir jika dihadapkan pada sebuah permasalahan. Dengan demikian, proses berpikir siswa dapat diketahui berdasarkan langkah-langkah yang dilakukan siswa dalam penyelesaian masalah.

Proses berpikir siswa dalam menyelesaikan masalah matematika kurang mendapat perhatian guru dalam pembelajaran (Arnold, 2011; Zaslavsky, 2008; Fardani dan Surya, 2017). Fakta di lapangan menunjukkan bahwa proses pembelajaran matematika masih didominasi dengan tuntutan untuk menghafalkan dan menguasai pelajaran sebanyak mungkin guna menghadapi ujian atau tes (Murdiono, 2010). Pembelajaran matematika hanya difokuskan untuk melatih siswa agar terampil menjawab tanpa harus memahami dan menguasai materi secara menyeluruh (Supriadi dkk, 2015; Haeley \& Hoyles, 2000). Hal ini dikarenakan tuntutan kelulusan siswa sekolah saat ini masih diukur berdasarkan hasil Ujian Nasional (UN) dan Ujian Akhir Sekolah (UAS). Dalam konteks ini, tuntutan untuk mengasah proses berpikir siswa dalam menyelesaikan masalah masih lemah.

Salah satu teori yang mengkaji tentang proses berpikir siswa adalah teori pemrosesan informasi (Hasan, 2016). Teori pemrosesan informasi merupakan teori belajar yang dicetuskan oleh Gagne (Rehalat, 2014). Teori pemrosesan informasi adalah teori belajar kognitif yang menjelaskan tentang pemrosesan, penyimpanan, dan pemanggilan kembali pengetahuan dari otak atau pikiran (Solso, 2008; Gagne, 1975). Teori pemrosesan informasi juga merupakan teori yang menekankan pada memori dan proses berpikir (Kusaeri, 2012). Berkaitan dengan memori dan proses yang terjadi dalam otak siswa, Gurbin juga mengemukakan bahwa teori pemrosesan informasi merupakan cara yang relatif mudah untuk memahami fungsi kompleks pada otak manusia yang diperlukan untuk berpikir dan bertindak (Amamah, 2016). Teori pemrosesan informasi tidak hanya berfokus pada perubahan perilaku yang nampak, melainkan juga pada pemrosesan informasi secara internal (di dalam diri), seperti seseorang memasukkan informasi dan menggunakan berbagai informasi tersebut (Kusaeri, 2017). Dengan demikian, teori pemrosesan informasi sangat berkaitan dengan proses berpikir siswa dalam menyelesaikan suatu masalah. 
Teori pemrosesan informasi terdiri dari beberapa komponen, antara lain komponen penyimpanan informasi dan komponen proses kognitif (Amamah dkk, 2016; Juliangkary dkk, 2012; Putra, 2017). Komponen penyimpanan informasi terdiri dari sensory memory/sensory register, short term memory (memori jangka pendek), dan long term memory (memori jangka panjang) (Sternberg, 2006; Woolfolk, 2008). Sedangkan komponen proses kognitif yaitu attention, perception, retrieval, rehearsal, dan encoding (Amamah dkk, 2016). Dalam konteks menyelesaikan masalah matematika, informasi yang diperoleh seorang individu dari lingkungan yaitu berupa soal atau masalah matematika yang akan diselesaikan, kemudian proses berpikirnya akan dianalisis berdasarkan komponen-komponen dalam teori pemrosesan informasi tersebut.

Model pemrosesan informasi secara umum disajikan sebagaimana Gambar 1. Model pemrosesan informasi dibuat untuk membantu pemahaman akan skema/bagan proses berpikir seseorang secara internal yang terjadi dalam otak atau pikiran manusia.

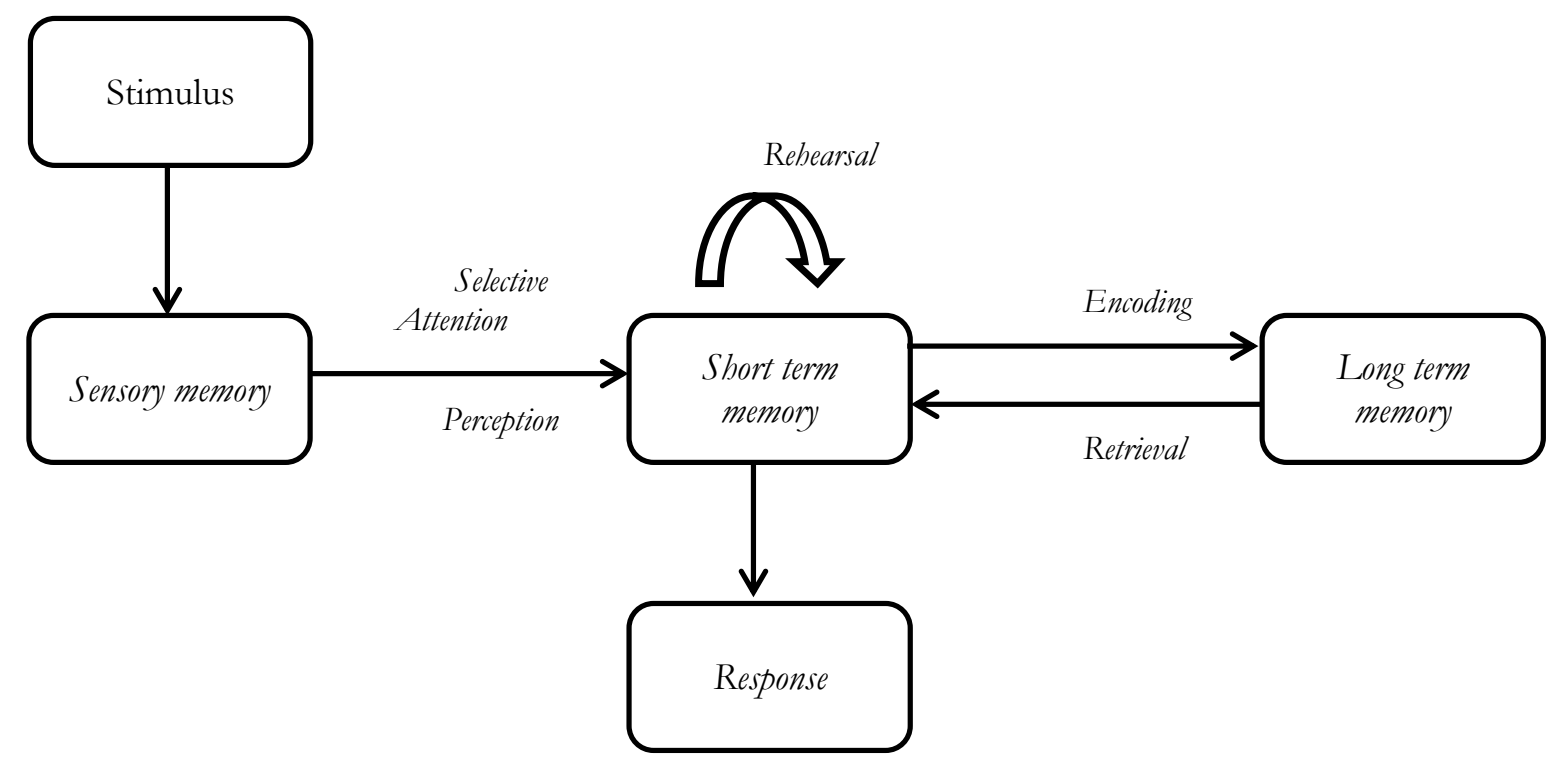

Gambar 1. Model Pemrosesan Informasi

Terjadinya pemrosesan informasi berawal dari adanya stimulus atau informasi yang masuk ke sensory memory/sensory register melalui alat indra (Hitipiew, 2009). Informasi yang masuk ke sensory register kemudian akan diseleksi (selective attention), informasi yang tidak diberikan perhatian akan langsung terlupakan, sedangkan informasi yang diberikan perhatian akan diteruskan ke dalam short term memory (memori jangka pendek). Hasil dari seleksi informasi akan menimbulkan persepsi.

Ketika informasi terus diberikan perhatian dan sering terjadi rehearsal (pengulangan), maka informasi yang sudah diberikan persepsi tersebut akan masuk ke long term memory (memori jangka panjang). Setelah berada di long term memory, informasi dapat diperoleh kembali dengan melakukan retrieval (pemanggilan informasi yang terdahulu) melalui strategi tertentu atau informasi tersebut akan terlupakan (gagal atau tidak dapat diperoleh kembali) karena adanya kekurangan dalam sistem memori atau penyimpanannya.

Berdasarkan uraian di atas, penting kiranya untuk mendeskripsikan proses berpikir siswa dalam menyelesaikan masalah matematika berdasarkan teori pemrosesan informasi untuk mengetahui alur berpikir dan pengetahuan siswa. Harapan dari penelitian ini adalah guru dapat mengembangkan suatu model pembelajaran matematika yang sesuai, sehingga kekurangan dalam proses berpikir siswa dapat diantisipasi. 


\section{METODE PENELITIAN}

Penelitian dilaksanakan di salah satu SMAN favorit di kota Surabaya kelas XI MIA-4. Penelitian ini dilakukan pada bulan Agustus - September 2017. Subjek penelitian ini adalah 6 (enam) siswa kelas XI yang sudah menerima materi trigonometri dasar. Dipilih siswa kelas XI yang sudah menempuh materi trigonometri dasar karena tujuan dari penelitian ini adalah untuk mengetahui proses berpikir yang melibatkan informasi/pengetahuan yang telah tersimpan dalam memori siswa.

Pemilihan subjek penelitian didasarkan pada hasil Tes Kemampuan Matematika (TKM) dan masukan dari guru bidang studi matematika. Subjek penelitian terdiri dari masing-masing dua siswa yang berkemampuan matematika tinggi, sedang, dan rendah. Keenam subjek yang terpilih kemudian diberikan soal tes tulis untuk dikerjakan dengan metode think aloud dan dilakukan wawancara untuk mengetahui proses berpikir siswa dalam menyelesaikan masalah matematika berdasarkan teori pemrosesan informasi.

Data dalam penelitian ini berupa hasil tes tertulis dengan menggunakan metode think aloud dan penjelasan-penjelasan siswa dalam wawancara. Instrumen yang digunakan dalam penelitian ini yaitu Tes Kemampuan Matematika (TKM), soal tes tulis, dan pedoman wawancara.

Proses analisis data dimulai dengan menelaah seluruh data yang tersedia dari berbagai sumber, yaitu hasil pengerjaan tes tulis dengan metode think aloud dan hasil transkrip wawancara. Kemudian dilakukan reduksi data, yaitu proses penyederhanaan yang dilakukan melalui seleksi, pemfokusan, dan pengabstrakan data mentah menjadi informasi yang bermakna. Setelah itu, pengkodean data dilakukan untuk memudahkan penganalisisan data. Pengkodean data berarti menerjemahkan data ke dalam kode. Setelah dilakukan pengkodean data, selanjutnya dilakukan penyajian data.Tahap terakhir yang dilakukan adalah penarikan kesimpulan.

\section{HASIL}

Deskripsi data dalam tulisan ini dibagi menjadi 3 bagian. Subjek yang berkemampuan matematika tinggi disimbolkan dengan S1 dan S2, subjek yang berkemampuan matematika sedang disimbolkan dengan S3 dan S4, dan subjek yang berkemampuan matematika rendah disimbolkan dengan S5 dan S6.

Proses berpikir S1 dan S2 dapat dilihat dari proses penyelesaian masalah yang dilakukan sejak diterimanya stimulus sampai dengan ditemukannya respon. Proses berpikir S1 dalam menyelesaikan masalah dimulai dengan membaca soal yang diberikan, kemudian informasi atau stimulus tersebut masuk ke dalam sensory register melalui indra penglihatan dan pendengaran. Setelah stimulus masuk ke sensory register, kemudian timbul attention. S1 melakukan selective attention dengan cara memilah informasi yang diperlukan, sehingga S1 dapat membedakan apa yang diketahui dan apa yang ditanyakan soal. S1 kemudian memiliki perception bahwa masalah berkaitan dengan materi trigonometri, sehingga untuk menentukan tinggi tiang bendera, S1 berencana menggunakan konsep ataupun rumus yang berkaitang dengan materi trigonometri.

Proses penyelesaian masalah oleh S1 dimulai dengan menentukan sudut-sudut yang belum diketahui menggunakan konsep jumlah sudut dalam segitiga. Hal ini berarti S1 juga mempunyai perception berkaitan dengan konsep jumlah sudut dalam segitiga, dan menerapkan perception tersebut di dalam short term memory. Ketika informasi diberikan persepsi oleh seseorang, maka informasi yang telah diberikan makna tersebut akan diteruskan ke short term memory. Kemudian S1 menentukan tinggi tiang menggunakan konsep perbandingan tangen. Hal ini berarti bahwa S1 melakukan retrieval konsep jumlah sudut dalam segitiga dan perbandingan tangen di long term memory. Adapun jawaban tertulis S1 terkait dengan proses perception dan retrieval dapat dilihat pada Gambar 2 berikut. 


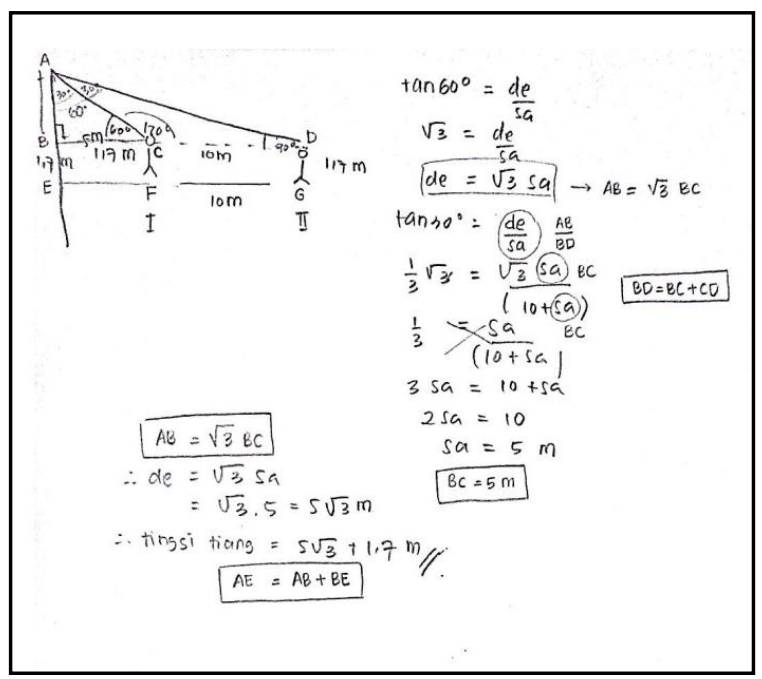

Gambar 2. Jawaban Tertulis S1

Berdasarkan Gambar 2 diperoleh hasil retrieval konsep perbandingan tangen dengan benar. Dengan kata lain, S1 mengingat konsep perbandingan tangen dengan baik. Kendati demikian, S1 mengalami lupa atau forgotten lost terhadap suatu konsep tertentu. Hal tersebut ditunjukkan ketika wawancara, S1 menyebutkan bahwa sebelumnya dia pernah mengerjakan soal yang serupa menggunakan konsep perbandingan tangen dan S1 hanya dapat mengingat konsep perbandingan tangen saja.Selain itu, S1 juga melakukan rehearsal (pengulangan) terhadap konsep perbandingan tangen. Respon berupa hasil jawaban yang diberikan S1 sudah benar.

Selanjutnya, proses berpikir S2 dalam menyelesaikan masalah dimulai dengan membaca soal yang diberikan di dalam hati, kemudian informasi atau stimulus tersebut masuk ke dalam sensory register melalui indra penglihatan. Setelah stimulus masuk ke sensory register, kemudian timbul attention. Dengan adanya attention, S2 dapat memilah informasi yang diperlukan sehingga S2 dapat mengetahui informasi apa saja yang diketahui dan apa yang ditanyakan pada soal. Setelah proses attention terjadi, maka muncul perception. S2 mempunyai strategi untuk menentukan tinggi tiang bendera dengan mencari sudut-sudut yang belum diketahui.Hal ini berarti perception S2 yaitu menggunakan konsep jumlah sudut dalam segitiga dan perbandingan sinus.

Kemudian S2 menerapkan perception tersebut di dalam short term memory. S2 menentukan sudut-sudut selain sudut elevasi dengan konsep jumlah sudut dalam segitiga, kemudian menggunakan perbandingan sinus untuk mencari tinggi tiang. Hal ini berarti bahwa S2 melakukan retrieval konsep jumlah sudut dalam segitiga dan perbandingan trigonometri di long term memory. Adapun jawaban tertulis S2 terkait dengan proses perception dan retrieval dapat dilihat pada Gambar 3 berikut. 


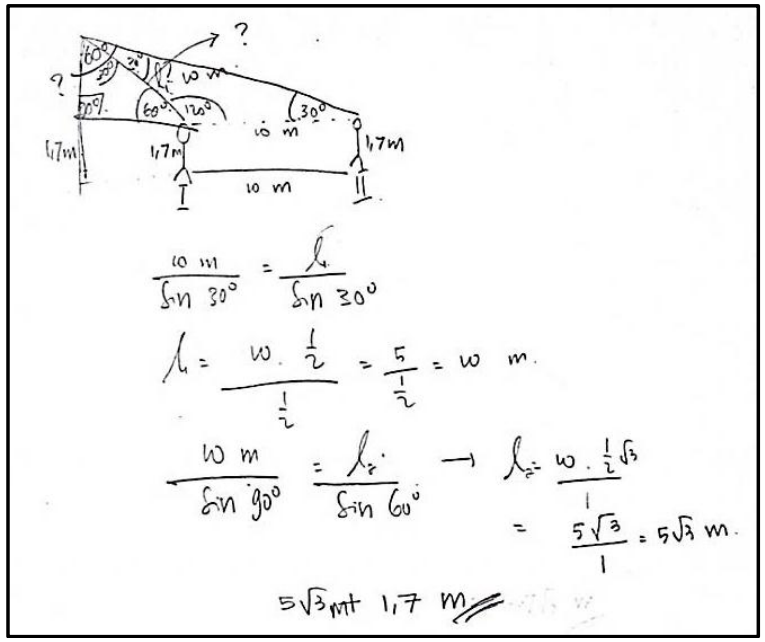

Gambar 3. Jawaban Tertulis S2

Berdasarkan Gambar 3 diperoleh hasil retrieval konsep perbandingan sinus dengan benar. Dengan kata lain, S2 mengingat konsep perbandingan sinus dengan baik. Kendati demikian, S2 mengalami lupa atau forgotten lost konsep perbandingan trigonometri yang lain. Ketika dilakukan wawancara, S2 menyebutkan bahwa dia kesulitan mengingat (lupa) dalam menggunakan rumus cos atau tangen untuk menyelesaikan soal. Hal itu karena S2 hanya dapat menerapkan konsep perbandingan tangen. Berdasarkan Gambar 3, terlihat juga bahwa S2 melakukan rehearsal (pengulangan) terhadap konsep perbandingan sinus. Kemudian respon yang diberikan S2 adalah benar.

Selanjutnya subjek yang berkemampuan matematika sedang adalah S3 dan S4. Proses berpikir S3 dimulai dengan mengamati dan membaca soal yang diberikan secara keras. Hal itu menunjukkan bahwa informasi atau stimulus masuk ke dalam sensory register melalui indra penglihatan dan indra pendengaran. Kemudian S3 melakukan seleksi attention, sehingga dapat membedakan informasi apa saja yang diketahui dan ditanyakan soal. Setelah itu, S3 memberikan perceptionbahwa masalah dapat diselesaikan menggunakan aturan sinus. S3 menjelaskan bahwa jika masalah yang diberikan digambarkan ke dalam bentuk sebuah segitiga maka akan terlihat suatu segitiga dengan sudut-sudut yang berhadapan kemudian diketahui sisi sudut sudut. Oleh karena itu, S3 lebih condong menggunakan aturan sinus. Adapun jawaban tertulis S3 terkait proses perception dan retrievaldapat dilihat pada Gambar 4 berikut.

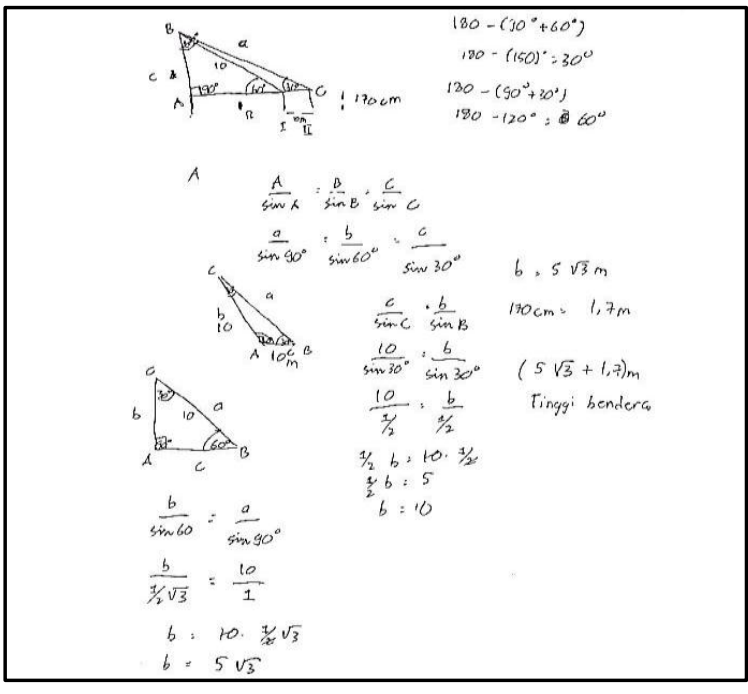

Gambar 4. Jawaban Tertulis S3 
Berdasarkan Gambar 4 terlihat bahwa S3 menentukan sudut-sudut selain sudut elevasi menggunakan konsep jumlah sudut dalam segitiga dengan benar. Hal ini berarti bahwa S3 melakukan retrieval konsep jumlah sudut dalam segitiga dengan baik. Kemudian S3 menerapkan perception dengan melakukan retrieval konsep aturan sinus di long term memory dengan baik, sehingga respon yang diberikan S3 benar.

Sementara proses berpikir S4 dimulai dari mengamati dan membaca soal, kemudian informasi atau stimulus masuk ke dalam sensory register melalui indra penglihatan dan indra pendengaran. Attention dan perception S4 sama dengan S3. Perception S4 dalam menyelesaikan masalah yaitu menggunakan aturan sinus. Adapun jawaban tertulis S4 terkait proses perception dan retrieval dapat dilihat pada Gambar 5 berikut.

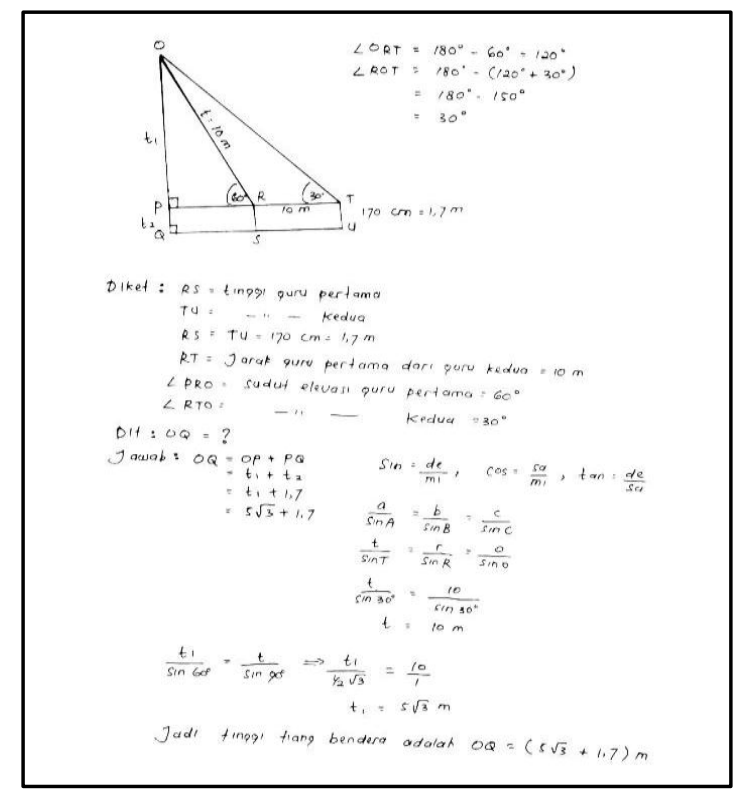

Gambar 5. Jawaban Tertulis S4

Berdasarkan Gambar 5, terlihat bahwa S4 menentukan $m \angle O R T$ dengan melakukan retrieval konsep sudut berpelurus dan jumlah sudut dalam segitiga. S4 menuliskan $m \angle O R T=$ $180^{\circ}-60^{\circ}=120^{\circ}$, kemudian juga menuliskan $m \angle R O T=180^{\circ}-\left(120^{\circ}+30^{\circ}\right)=30^{\circ}$. Hal itu menunjukkan bahwa S4 melakukan retrieval terhadap konsep sudut berpelurus dan jumlah sudut dalam segitiga.

Kemudian S4 menentukan panjang sisi $t$ menggunakan aturan sinus dengan menuliskan $\frac{t}{\sin 30^{\circ}}=\frac{10}{\sin 30^{\circ}}$ sehingga $t=10 \mathrm{~m}$. Selanjutnya, S4 menentukan tinggi tiang $t_{1}$ dan menuliskan $\frac{t_{1}}{\sin 60^{\circ}}=\frac{t}{\sin 90^{\circ}}$ kemudian $\frac{t_{1}}{1 / 2^{\sqrt{3}}}=\frac{10}{1}$, sehingga diperoleh $t_{1}=5 \sqrt{3} \mathrm{~m}$. Proses retrieval konsep yang dilakukan S4 sebagian besar sudah benar, sehingga respon yang diberikan S4 juga benar. Kendati demikian, S4 mengalami kesalahan atau retrieval failure dalam menjelaskan pengertian sudut elevasi. S4 menyebutkan bahwa sudut elevasi adalah sudut lancip yang besarnya kurang dari $90^{\circ}$. Selanjutnya untuk subjek S5 berdasarkan Gambar 8, proses berpikir S5 dimulai dengan memodelkan masalah ke dalam bentuk gambar segitiga. S5 memisalkan guru pertama sebagai $y$ dan guru kedua sebagai $x$. Kemudian S5 menuliskan jarak antara $x$ dan $y$ sama dengan $10 \mathrm{~m}$, tinggi kedua guru $170 \mathrm{~cm}$, serta besar sudut elevasi guru pertama $60^{\circ}$ dan sudut elevasi guru kedua $30^{\circ}$. SelanjutnyaS5 menentukan tinggi tiang dengan menggunakan rumus trigonometri dasar. 
S5 memisalkan jarak guru pertama ke tiang dengan menuliskan $a=y$. S5 juga menuliskan jarak guru kedua ke tiang adalah $10+a=x$. Setelah itu, S5 memisalkan $B=C \times$ $\frac{1}{2} \sqrt{3}=a \sqrt{3}$ dan $a=C \times \frac{1}{2}$. S5 juga menentukan panjang sisi $D$ dengan mensubstitusikan $a=C \times \frac{1}{2}=\frac{C}{2}$ ke persamaan $x=10+a$, sehingga diperoleh jawaban $D=\sqrt{3}(5+C)$. S5 menuliskan $\sin 30^{\circ}=\frac{B}{D}$, kemudian mensubstitusikan $D=\sqrt{3}(5+C)$ ke dalam $\frac{1}{2} D=B$, sehingga diperoleh persamaan $\frac{5}{2} \sqrt{3}+\frac{C}{2} \sqrt{3}=\frac{C}{2} \sqrt{3}$. Setelah itu, S5 melakukan pengulangan dalam proses perhitungan untuk menentukan panjang sisi D dan C. Kendati demikian, penyelesaian yang dilakukan masih terdapat kesalahan dalam menentukan panjang sisi C. Respon yang diberikan S5 kurang tepat, hal itu karena S5 mengalami kesalahan dalam proses perhitungan. Selain itu, S5 juga ragu terhadap kebenaran jawaban yang diberikan.

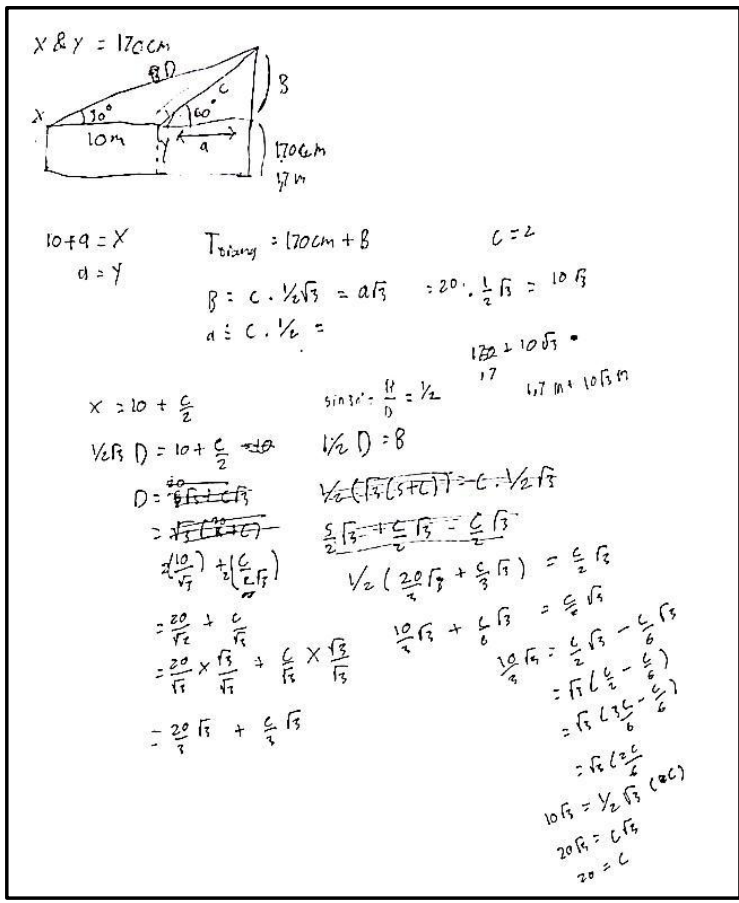

Gambar 6. Jawaban Tertulis S5

Sementara proses berpikir S6 dimulai dengan memodelkan masalah yang diberikan ke dalam dua buah gambar segitiga. Pada gambar segitiga yang pertama, S6 memisalkan tinggi tiang bendera sebagai $y$ dan jarak guru pertama ke tiang sebagai $x$ yang panjangnya $10 \mathrm{~m}$. S6 kemudian memilah informasi yang diperlukan dengan memberikan attention.Selanjutnya, S6memberikan persepsi bahwa untuk menentukan tinggi tiang bendera $y$ pada segitiga pertama dapat digunakan konsep perbandingan tangen.

Lebih lanjut S6 menerapkan perception dengan melakukan retrieval di long term memory. Konsep-konsep yang diperlukan S6 dalam menyelesaikan masalah dipanggil dari long term memory (memori jangka panjang) untuk diterapkan di short term memory (memori jangka pendek). Adapun jawaban tertulis S6 terkait proses perception dan retrieval dapat dilihat pada Gambar 9 berikut. 


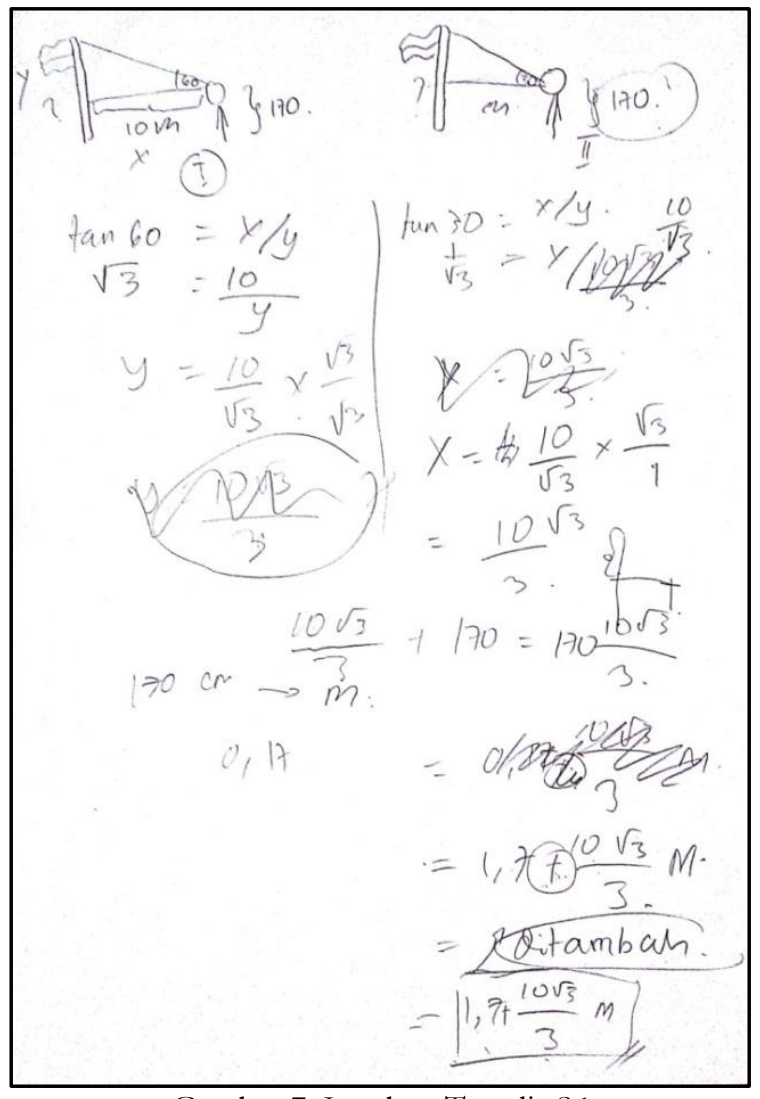

Gambar 7. Jawaban Tertulis S6

Berdasarkan Gambar 7, diperoleh hasil retrieval konsep perbandingan tangen yang kurang tepat dari gambar segitiga pertama. S6 menuliskan $\tan 60^{\circ}=\frac{x}{y}$, padahal tangen suatu sudut berarti perbandingan antara sisi depan dan sisi samping segitiga dari sudut tersebut. Dengan kata lain, S6 mengalami kesalahan atau retrieval failure dalam menerapkan konsep perbandingan tangen. Selain itu, S6 juga mengalami lupa atau forgotten lost terhadap pengertian sudut elevasi. S6 menyebutkan bahwa sudut elevasi adalah sudut lancip. Ketika dilakukan wawancara, S6 menyebutkan bahwa dia merasa belum pernah mengerjakan soal yang serupa sehingga mengalami kesulitan. Pada Gambar 7 juga dapat diketahui bahwa S6 telah melakukan rehearsal (pengulangan) terhadap konsep perbandingan tangen. Respon yang diberikan S6 kurang tepat.

\section{PEMBAHASAN}

Adapun skema berpikir S3 dan S4 dalam menyelesaikan masalah matematika berdasarkan teori pemprosesan informasi disajikan pada Gambar 8. Berdasarkan Gambar 8 di bawah ini, proses berpikir siswa yang berkemampuan matematika tinggi dimulai dari adanya stimulus berupa soal trigonometri, kemudian mulai melakukan proses retrieval (pemanggilan kembali) untuk membuat penarikan kesimpulan atau respon berupa hasil jawaban. Dalam proses menyelesaikan masalah matematika, semua komponen dari teori pemrosesan informasi harus bekerja dengan baik agar menghasilkan kesimpulan atau respon yang benar terutama komponen attention, perception, dan long term memory. Hal ini sesuai dengan pendapat Lunenburg \& Green (2012) bahwa komponen attention, perception, dan long term memory merupakan landasan berpikir bagi siswa. Dengan demikian, ketiga komponen pemrosesan informasi tersebut memegang peranan yang penting dalam proses menyelesaikan masalah matematika. 
Dua orang guru dengan tinggi badan yang sama yaitu $170 \mathrm{~cm}$ sedang berdiri memandang puncak tiang bendera di sekolahnya. Guru pertama berdiri tepat $10 \mathrm{~m}$ di depan guru kedua. Jika sudut elevasi guru pertama $60^{\circ}$ dan guru kedua $30^{\circ}$, maka dapatkah Anda menghitung tinggi tiang bendera tersebut?

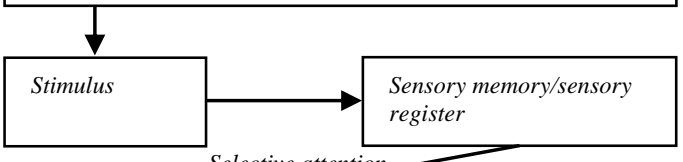

Selective attention

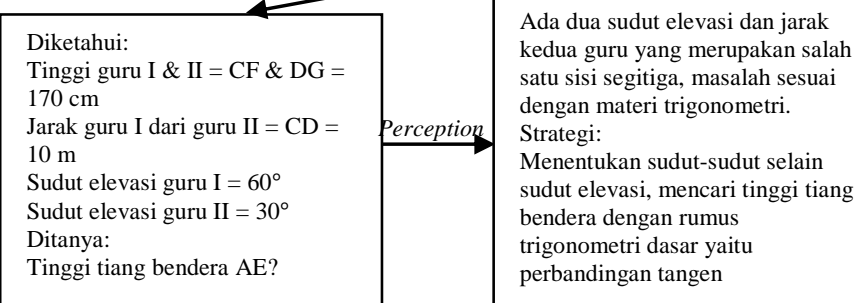

\section{Long Term Memory}

\begin{tabular}{|c|c|c|c|}
\hline \multirow{6}{*}{$\begin{array}{l}\text { Kejadia } \\
\text { n } \\
\text { - Latihan } \\
\quad \text { Soal } \\
\text { - Penjela } \\
\quad \text { san } \\
\quad \text { Guru } \\
\text { - Catatan }\end{array}$} & Konsep & \multirow{3}{*}{ 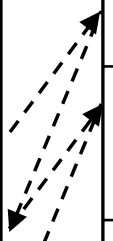 } & $170 \mathrm{~cm}=1,7 \mathrm{~m}$ \\
\hline & $\begin{array}{l}\text { Mengubah satuan } \\
\mathrm{cm} \text { ke } \mathrm{m}\end{array}$ & & \multirow{2}{*}{$\begin{array}{l}\text { Sudut elevasi adalah sudut yang } \\
\text { terbentuk antara garis penglihatan } \\
\text { guru ke puncak tiang bendera dan } \\
\text { garis yang mendatar. }\end{array}$} \\
\hline & \multirow{2}{*}{$\begin{array}{l}\text { Pengertian sudut } \\
\text { elevasi }\end{array}$} & & \\
\hline & & \multirow{4}{*}{ 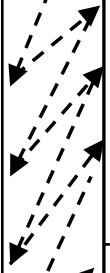 } & \multirow{3}{*}{$\begin{array}{l}180^{\circ}-60^{\circ}=120^{\circ} \\
180^{\circ}-\left(90^{\circ}+30^{\circ}\right)=60^{\circ}(\text { sudut } \\
\text { puncak tiang) } \\
180^{\circ}-\left(60^{\circ}+90^{\circ}\right)=30^{\circ} \text { (setengah } \\
\text { sudut puncak tiang pertama) } \\
180^{\circ}-\left(120^{\circ}+30^{\circ}\right)=30^{\circ} \\
\text { (setengah sudut puncak tiang } \\
\text { kedua) }\end{array}$} \\
\hline & Sudut berpelurus & & \\
\hline & $\begin{array}{l}\text { Jumlah sudut } \\
\text { dalam segitiga }\end{array}$ & & \\
\hline & Sudut siku-siku & & \multirow{2}{*}{$\sin =\frac{d e}{m i}, \cos =\frac{s a}{m i}, \tan =\frac{d e}{s a}$} \\
\hline & \multirow{2}{*}{$\begin{array}{l}\text { Trigonometri } \\
\text { dasar }\end{array}$} & & \\
\hline & & & \multirow{2}{*}{$\tan 30^{\circ}=\frac{1}{3} \sqrt{3}$ dan $\tan 60^{\circ}=\sqrt{3}$} \\
\hline & $\begin{array}{l}\text { Nilai sudut } \\
\text { istimewa }\end{array}$ & & \\
\hline & $\begin{array}{l}\text { Perbandingan } \\
\text { tangen }\end{array}$ & | & \multirow{3}{*}{$\begin{array}{l}\tan 60^{\circ}=\frac{d e}{s a} \\
\sqrt{3}=\frac{d e}{s a} \\
d e=\sqrt{3} s a\end{array}$} \\
\hline & Perkalian & & \\
\hline & \multirow{2}{*}{$\begin{array}{l}\text { Perkalian, } \\
\text { pembagian, } \\
\text { penjumlahan, } \\
\text { kemudian } \\
\text { substitusi } s a= \\
5 \mathrm{~m} \text { ke dalam } \\
d e=\sqrt{3} \mathrm{sa}\end{array}$} & \multirow{4}{*}{ 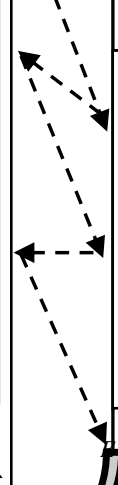 } & \\
\hline & & & \multirow{2}{*}{$\begin{array}{c}\tan 30^{\circ}=\frac{d e}{s a} \quad d e=\sqrt{3} s a \\
\frac{1}{3} \sqrt{3}=\frac{\sqrt{3} \underline{\underline{s}}=\sqrt{3} \times 5}{(10+s a)} \sqrt{3} m \\
\frac{1}{3}=\frac{s a}{(10+s a)} \\
3 s a=10+s a \\
s a=5 \mathrm{~m}\end{array}$} \\
\hline & $\begin{array}{l}\text { Penarikan } \\
\text { kesimpulan }\end{array}$ & & \\
\hline & & & $\begin{array}{l}\text { Tinggi tiang bendera adalah } \\
5 \sqrt{3}+1,7 m\end{array}$ \\
\hline
\end{tabular}
informasi, (b) Skema berpikir S2 dalam menyelesaikan masalah matematika berdasarkan teori pemprosesan informasi
Dua orang guru dengan tinggi badan yang sama yaitu 170 $\mathrm{cm}$ sedang berdiri memandang puncak tiang bendera $\mathrm{d}$ sekolahnya. Guru pertama berdiri tepat $10 \mathrm{~m}$ di depan guru kedua. Jika sudut elevasi guru pertama $60^{\circ}$ dan guru kedua $30^{\circ}$, maka dapatkah Anda menghitung tinggi tiang bendera tersebut?

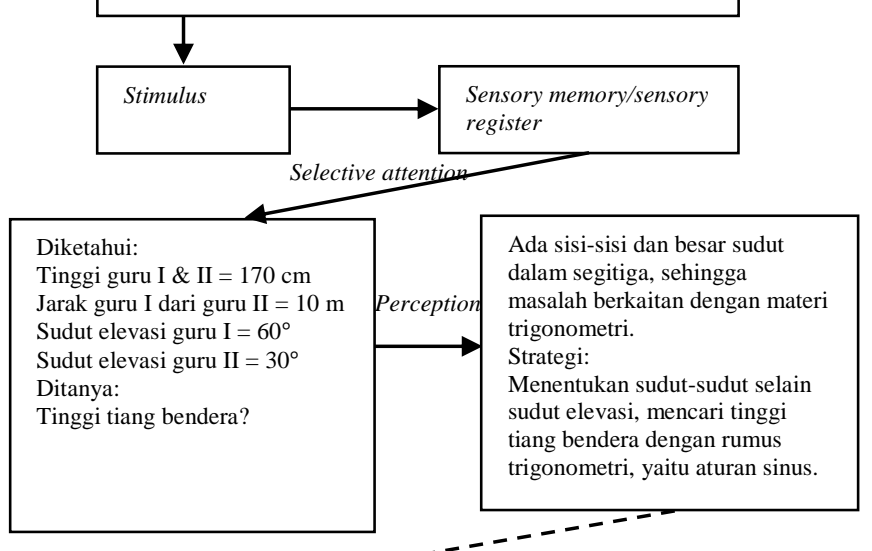

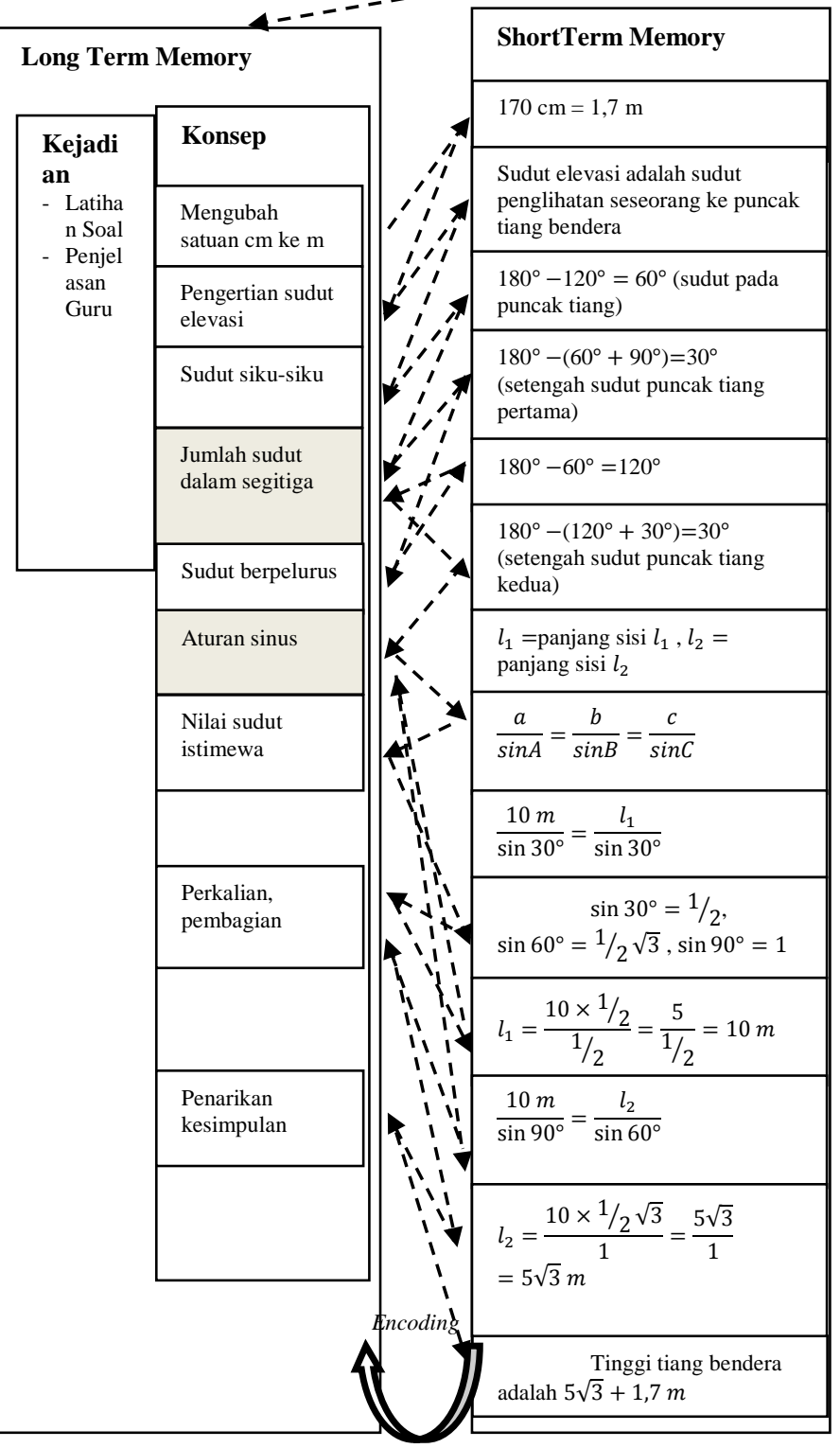

(b) 
Siswa yang berkemampuan matematika tinggi menerima stimulus dengan mengamati dan membaca soal yang diberikan. Kemudian informasi atau stimulus berupa soal tersebut secara utuh masuk ke sensory register melalui receptors (alat indra) yaitu indra penglihatan ataupun indra pendengaran. Hal ini sesuai dengan penelitian Ngilawajan (2013) yang mengatakan bahwa membaca soal dengan cermat dan teliti dapat menunjukkan bahwa siswa memberi perhatian terhadap informasi yang diterima, sehingga informasi tersebut dapat dipahami dan diingat. Attention merupakan cara untuk memindahkan stimulus dari sensory register ke dalam short term memory. Dengan demikian, dapat diketahui bahwa dengan adanya attention maka siswa mampu mengidentifikasi permasalahan yang diberikan, sehingga siswa yang berkemampuan matematika tinggi dapat membedakan informasi apa yang diketahui dan apa yang ditanyakan soal.

Setelah siswa melakukan selective attention (mengidentifikasi permasalahan yang diberikan) dan mendapatkan informasi yang cukup maka siswa akan memberikan perception (persepsi) terhadap informasi berupa soal. Siswa berkemampuan matematika tinggi mempunyai persepsi bahwa yang harus dilakukan setelah membaca soal adalah menentukan tinggi tiang bendera menggunakan rumus trigonometri. Perception (persepsi) yang diberikan siswa sudah benar, hal ini karena siswa sudah mempunyai pengetahuan dan pengalaman untuk menyelesaikan masalah. Setiap pengalaman dan pengetahuan yang tersimpan di long term memory (memori jangka panjang) dapat mempengaruhi persepsi individu terhadap stimulus yang datang (Amamah dkk, 2016). Pengalaman dan pengetahuan yang pernah diperoleh siswa dan tersimpan di dalam long term memory dapat membantu siswa dalam menyelesaikan masalah. Berdasarkan hasil wawancara yang dilakukan terhadap siswa yang berkemampuan matematika tinggi diketahui bahwa siswa sebelumnya pernah menyelesaikan masalah trigonometri yang serupa.

Setelah dari sensory register, informasi selanjutnya memasuki short term memory. Di dalam short term memory, informasi yang telah diperoleh berdasarkan seleksi (selective attention) akan diolah lebih lanjut. Informasi lama berupa pengetahuan atau konsep-konsep yang dibutuhkan dalam menyelesaikan masalah dipanggil dari long term memory menuju short term memory. Proses pemanggilan kembali informasi inilah yang dimaksud retrieval (Riyadi, 2011).

Pada tahap retrieval, siswa yang berkemampuan matematika tinggi memanggil kembali konsep yang ada pada long term memory.Sesuai dengan perception (persepsi) siswa sebelumnya bahwa masalah dapat diselesaikan menggunakan konsep trigonometri, namun dalam merealisasikannya siswa juga menentukan besar sudut-sudut selain sudut elevasi yang belum diketahui dengan melakukan retrieval terhadap konsep jumlah sudut dalam segitiga. Selain itu, siswa juga melakukan retrieval konsep perbandingan trigonometri, aturan sinus, nilai sudut-sudut istimewa, melakukan proses perhitungan menggunakan operasi bilangan dan metode substitusi dengan baik. Kendati demikian, siswa yang berkemampuan matematika tinggi juga mengalami kesulitan pada tahap retrieval karena mengalami lupa atau forgotten lost.

Siswa yang berkemampuan matematika tinggi kesulitan dalam memanggil suatu konsep tertentu dari long term memory, namun respon yang diberikan sudah benar. Hal ini dikarenakan siswa yang berkemampuan matematika tinggi sebelumnya pernah menyelesaikan masalah materi trigonometri. Siswa yang berkemampuan matematika tinggi juga melakukan rehearsal (pengulangan) terhadap rumus ataupun konsep trigonometri. Selama proses penyelesaian masalah, di dalam short term memory siswa terjadi pula encoding (penyimpanan informasi dari short term memory ke long term memory). Baik informasi baru yang disimpan atau informasi lama yang disimpan ulang dari short term memory menuju long term memory, sehingga informasi dapat dipanggil kembali pada saat dibutuhkan. 
Adapun skema berpikir S3 dan S4 dalam menyelesaikan masalah matematika berdasarkan teori pemprosesan informasi disajikan pada Gambar 9.

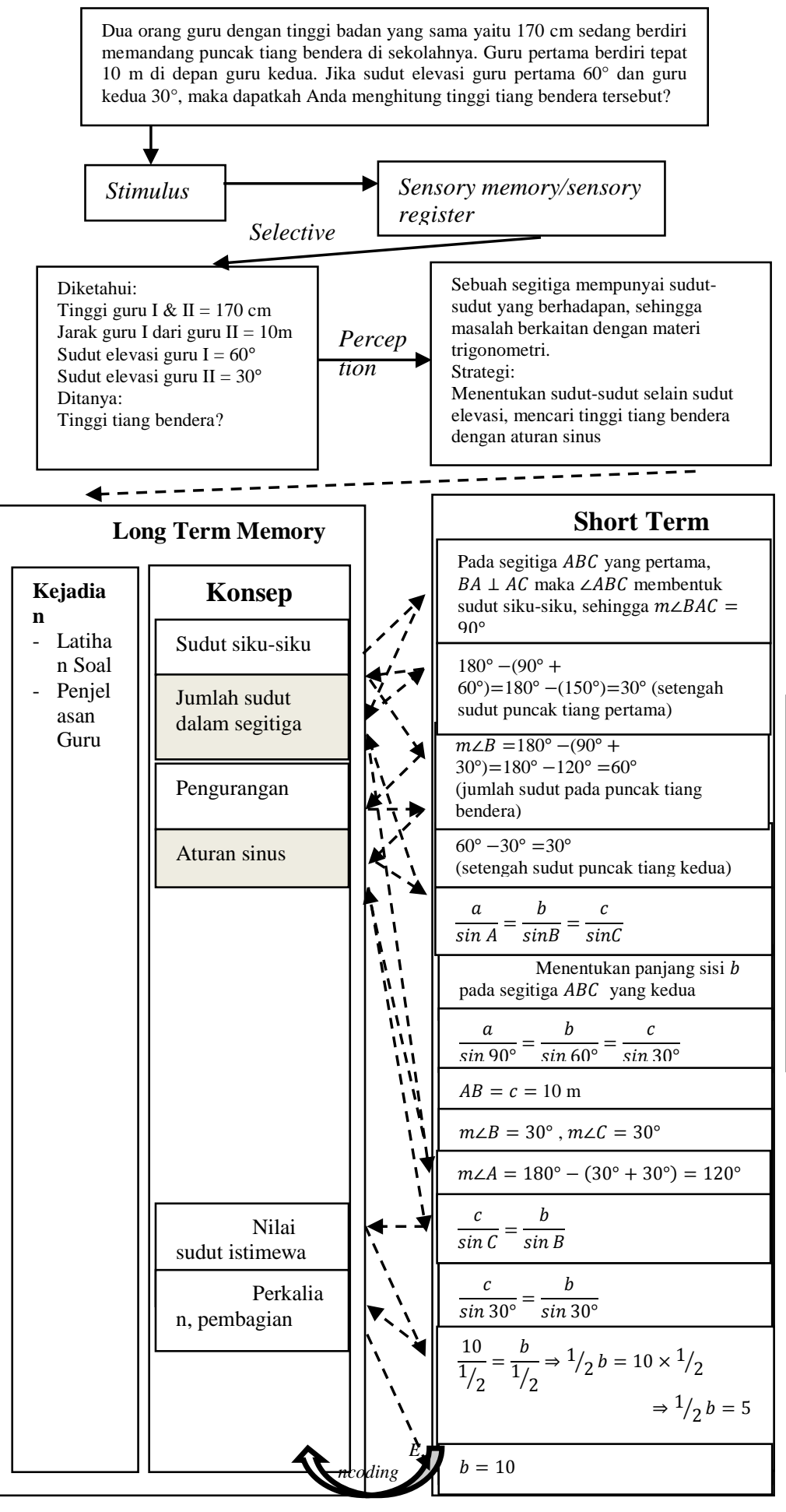

(a)

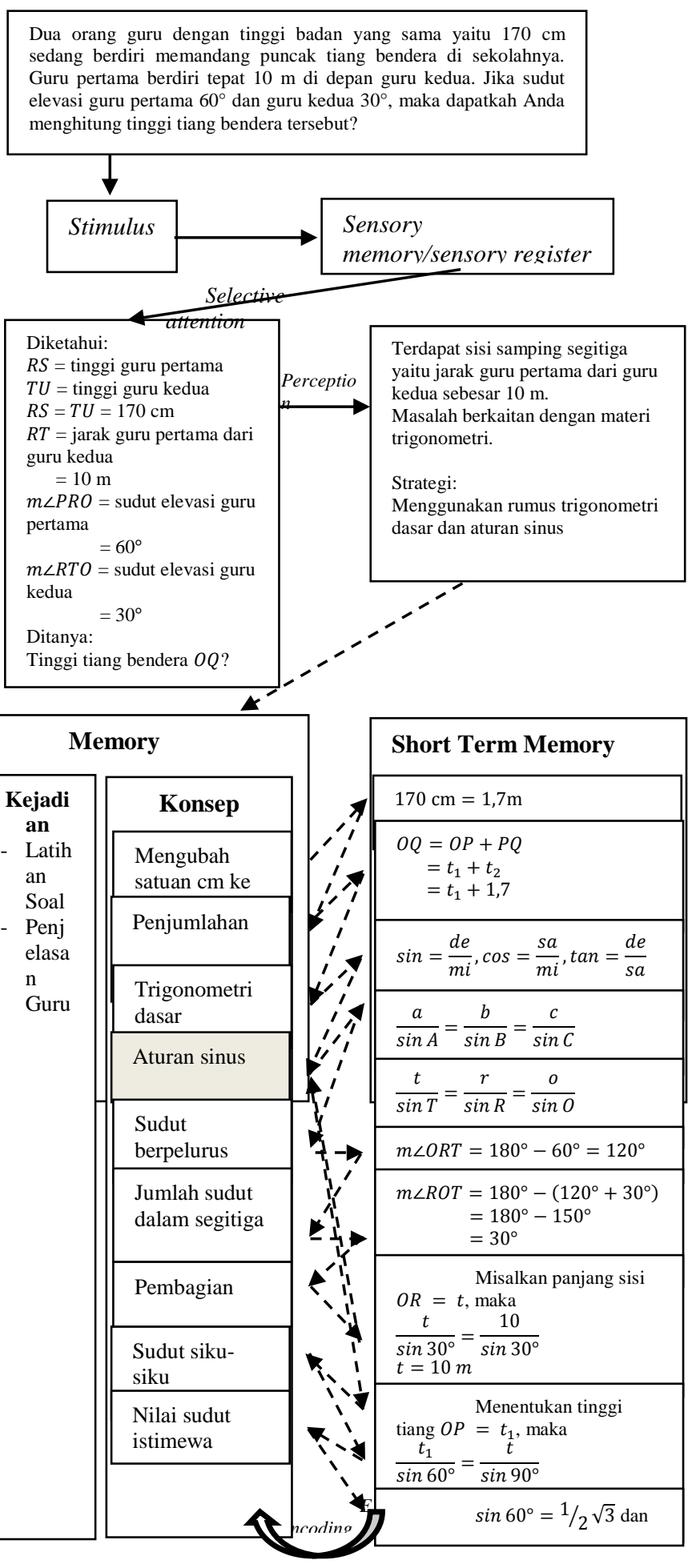

(b)

Gambar 9. (a) Skema berpikir S3 dalam menyelesaikan masalah matematika berdasarkan teori pemprosesan informasi, (b) Skema berpikir S4 dalam menyelesaikan masalah matematika berdasarkan teori pemprosesan informasi 
Berdasarkan uraian S3 dan S4 pada Gambar 9, proses berpikir siswa yang berkemampuan matematika sedang dalam menyelesaikan masalah dimulai dari adanya stimulus berupa masalah trigonometri. Selanjutnya, stimulus masuk ke sensory register melalui receptors (alat indra) yaitu indra penglihatan dan indra pendengaran dengan cara mengamati dan membaca soal yang diberikan. Hal ini sesuai dengan penelitian Amamah dkk (2016) bahwa informasi masuk ke sensory register melalui aktivitas membaca.

Siswa yang berkemampuan matematika sedang memberikan attention (perhatian) dengan cara memilah informasi yang ada pada soal agar informasi terfokus. Prinz menyatakan bahwa attention terfokuskan pada beberapa informasi, dengan memberikan perhatian atau makna terhadap informasi baru, sehingga informasi tersebut mungkin dapat terhubung dengan pengetahuan yang sudah ada (Putra dkk, 2017). Sehingga, siswa yang berkemampuan matematika sedang dapat membedakan apa yang diketahui dan apa yang ditanyakan pada soal. Attention (perhatian) yang terjadi dapat terfokus pada informasi atau stimulus secara lengkap. Setelah siswa memberikan attention dengan cara memilah informasi yang ada pada soal, maka akan timbul perception (persepsi). Perception siswa adalah masalah yang diberikan berkaitan dengan materi trigonometri, sehingga untuk menyelesaikan masalah tersebut mereka akan menggunakan aturan sinus.

Siswa yang berkemampuan matematika sedang kemudian melakukan retrieval dengan memanggil kembali informasi atau konsep dari long term memory (memori jangka panjang). Selanjutnya, siswa melakukan rehearsal dengan melakukan pengulangan konsep yang sudah mengalami retrieval tersebut pada short term memory. Ketika siswa yang berkemampuan matematika sedang melakukan retrieval (pemanggilan kembali), ada seorang siswa yang juga mengalami kesalahan konsep. Hal tersebut dikarenakan konsep yang ada pada long term memory siswa mengalami fragmented atau tidak saling terhubung (Putra dkk, 2017). Akibatnya, siswa menjelaskan konsep yang salah atau mengalami retrieve failure (kegagalan dalam memanggil informasi yang sudah disimpan) serta telah menyimpan kesalahan tersebut di long term memory.

Siswa yang berkemampuan matematika sedang melakukan encoding (penguatan) berupa kelancaran dalam menjelaskan jawaban yang sudah dikerjakan pada saat wawancara, sehingga respon yang diberikan benar. Hasan (2016) mengatakan bahwa proses berpikir siswa akan berjalan dengan benar sebagaimana yang diharapkan apabila komponen teori pemrosesan informasi yang ada dari stimulus sampai dengan long term memory pada diri siswa berfungsi dengan baik dan benar pula. Hal tersebut menunjukkan bahwa komponen penyimpanan informasi dan proses kognitif siswa yang berkemampuan matematika sedang telah berfungsi dengan baik meskipun sempat terjadi kesalahan dalam menjelaskan pengertian sudut elevasi.

Adapun skema berpikir S5 dan S6 dalam menyelesaikan masalah matematika berdasarkan teori pemprosesan informasi disajikan pada Gambar 10. 

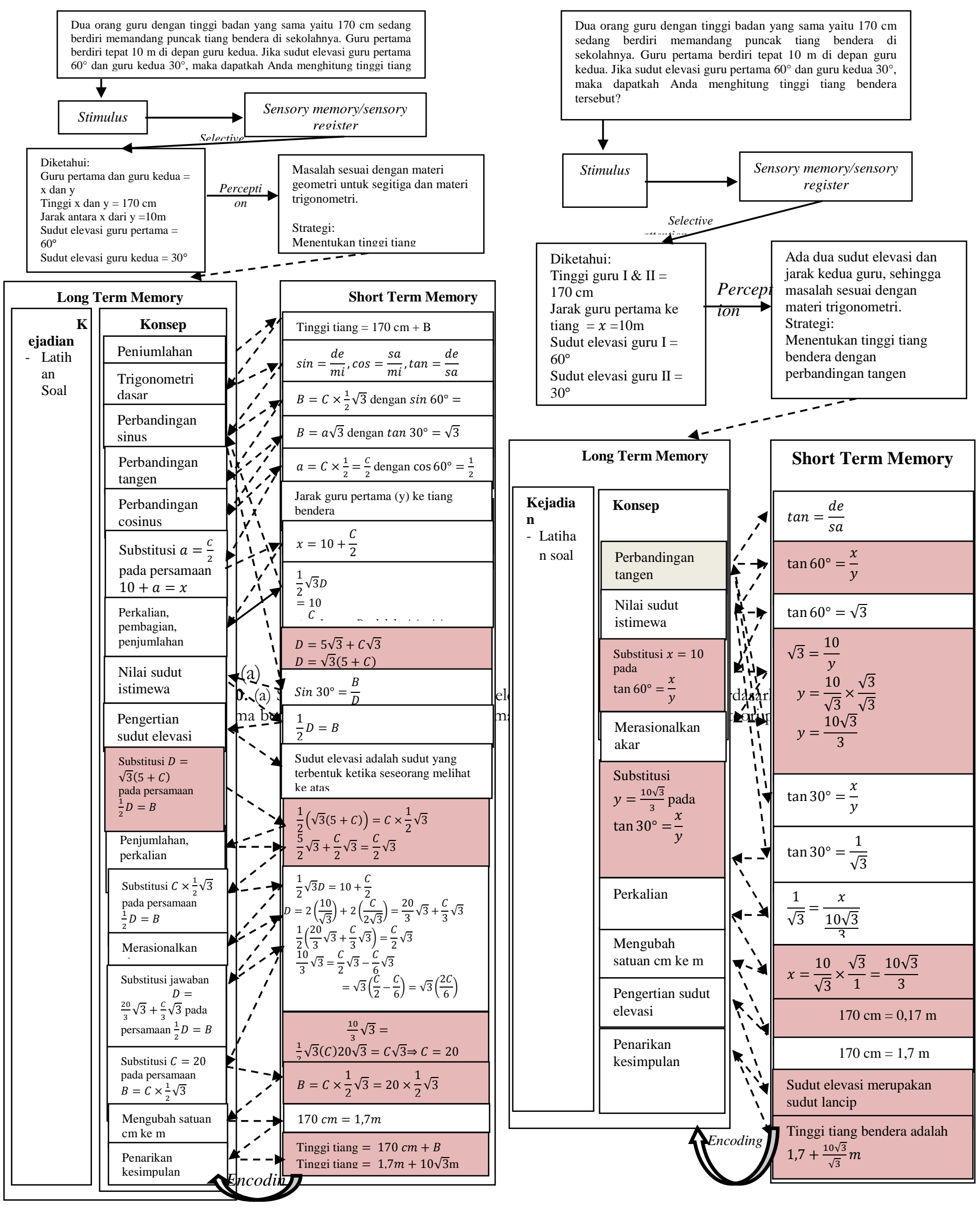
Gambar 10. (a) Skema berpikir S5 dalam menyelesaikan masalah matematika berdasarkan teori pemprosesan informasi, (b) Skema berpikir S6 dalam menyelesaikan masalah matematika berdasarkan teori pemprosesan informasi

Siswa yang berkemampuan matematika rendah melakukan retrieval terhadap konsep-konsep yang dibutuhkan dalam menyelesaikan masalah dari long term memory. Pada proses retrieval inilah siswa sering mengalami kesalahan. Siswa melakukan retrieval pada informasi yang dibutuhkan dengan menuliskan pengetahuan yang dimiliki kemudian dikaitkan dengan informasi yang diterimanya. Hal tersebut sesuai dengan penelitian Wijaya dkk (2016), ketika menyelesaikan masalah matematika maka siswa akan menghubungkan situasi-situasi pada masalah dengan pengalaman dan pengetahuan sebelumnya yang siswa miliki.

Siswa yang berkemampuan matematika rendah menggunakan rumus trigonometri. Hal ini sesuai dengan perception sebelumnya, tetapi dalam merealisasikannya siswa yang berkemampuan matematika rendah juga melakukan operasi perkalian, pengurangan, dan substitusi. Ketika menentukan sisi-sisi segitiga yang belum diketahui, siswa yang berkemampuan matematika rendah sering mengalami kesalahan dalam perhitungan. Hal itu dikarenakan siswa kurang teliti, mengalami lupa atau forgotten lost, atau dengan kata lain konsep trigonometri maupun operasi bilangan tidak tersimpan dengan baik di long term memory. Siswa juga melakukan retrieval konsep yang kurang tepat sehingga respon yang diperoleh salah dan solusi tidak relevan. Respon siswa yang salah dikarenakan konsep-konsep yang dibutuhkan tidak tersimpan dengan baik di long term memory siswa.

Beberapa informasi akan disimpan ulang di long term memory, setelah informasi diproses di short term memory, baik itu informasi yang baru mereka dapatkan atau informasi yang telah mereka dapatkan dan dipanggil kembali. Hal ini disebut dengan proses encoding. Siswa dikatakan melakukan encoding jika siswa dapat menjelaskan jawaban yang diperoleh. Proses penyelesaian masalah diasumsikan tersimpan di long term memory meskipun hasil yang diberikan salah. Jika terdapat siswa yang tidak dapat menjelaskan jawaban yang diperoleh atau siswa lupa bagaimana cara mendapatkan jawabannya, maka tidak semua proses yang dilakukan siswa masuk ke long term memory.

Proses encoding yang terjadi pada siswa terlihat kelancarannya pada saat wawancara dilakukan. Proses encoding yang dilakukan berupa penguatan terhadap sejumlah konsep-konsep yang sudah dilakukan retrieval dari long term memory (memori jangka panjang).Pada jawaban-jawaban yang diyakini benar, terjadi encoding terhadap konsep-konsep yang sudah dipanggil dari long term memory (memori jangka panjang) sebelumnya (Hasan, 2016).

\section{KESIMPULAN}

Informasi atau stimulus berupa soal yang diterima siswa yang berkemampuan matematika tinggi, sedang, dan rendah masuk ke dalam sensory register melalui alat indra, yaitu indra penglihatan dan indra pendengaran. Kemudian attention terjadi setelah siswa membaca soal dan timbul perception. Selanjutnya, siswa merealisasikan perception dengan melakukan retrieval konsep yang dibutuhkan dari long term memory untuk menyelesaikan masalah yang diberikan. Ketika melakukan retrieval, siswa yang berkemampuan matematika tinggi mengalami lupa atau forgotten lost terhadap suatu konsep tertentu. Sedangkan bagi siswa yang berkemampuan matematika sedang, terdapat seorang siswa yang mengalami kesalahan atau retrieval failure dalam menjelaskan konsep terkait pengertian sudut elevasi. Kemudian bagi siswa yang berkemampuan matematika rendah, konsep-konsep yang dibutuhkan short term memory tidak tersimpan dengan baik oleh long term memory, sehingga siswa sering mengalami kesalahan dan lupa. 


\section{DAFTAR PUSTAKA}

Amamah, S, dkk.(2016). Proses Berpikir Siswa SMP Bergaya Kognitif Field Dependent dan Field Independent dalam Menyelesaikan Masalah Berdasarkan Teori Pemrosesan Informasi, Jurnal Pendidikan, 1(2), 237-245.

Amamah, S.(2016). Proses Berpikir Siswa SMP Field Dependent dan Field Independent dalam Menyelesaikan Masalah Bangun Datar Ditinjau dari Teori Pemrosesan Informasi. Tesis tidak diterbitkan. Malang: Universitas Negeri Malang.

Arnold, J. (2011). Attention to Affect in Language Learning. Anglistik International Journal of English Studies, 22(1), 11-22.

Ernest, P. (2004). The Philosophy of Mathematics Education. UK: Taylor \& Francis.

Fardani, Z. \& Surya, E. (2017). Meningkatkan Kemampuan Berpikir Kritis dalam Pembelajaran Matematika untuk Membangun Karakter Bangsa. Diakses dari ResearchGate, pada 12 Desember 2017.

Gagne, R.M. (1975). Esentials of Learning for Instruction. New York: Holt, Rinehart, and Wiston.

Hasan, B. (2016). Proses Berpikir Mahasiswa dalam Mengkonstruksi Bukti Menggunakan Induksi Matematika Berdasarkan Teori Pemrosesan Informasi. Jurnal Apotema, 2(1), 33-40.

Haji, S. (2013). Pertanyaan yang Memicu Kemampuan Berpikir Matematis Siswa dalam Pembelajaran Matematika. Artikel yang Dimuat dalm Prosiding Seminar Nasional Matematika dan Pendidikan Matematika. Bandung: STKIP Siliwangi Bandung.

Haeley, L \& Hoyles, C. (2000). A Study of Proof Conception in Algebra. Jurnal Research for Mathematics Education, 31(4), 396-428.

Hitipiew, L. (2009). Belajar dan Pembelajaran. UM, Malang: Fakultas Ilmu Pendidikan.

Jorczak, R. L. (2011). An Information Processing Perspective on Divergence and Convergence in Collaborative Learning. International Journal of Computer-Supported Collaborative Learning, 6(2), 207-221.

Juliangkary, E, dkk. (2012). Proses Berpikir Mahasiswa Matematika IKIP Mataram dalam Pembuktian Keterbagian Berdasarkan Teori Pemrosesan Informasi. Jurnal Media Pendidikan Matematika, $1(2), 120-126$.

Khan, L. (2015). What is Mathematics - an Overview, International Journal of Mathematics and Computational Science, 1(3), 98-101.

Kusaeri, K. (2012). Pengembangan Tes Diagnostik dengan Menggunakan Model DINA, untuk Mendapatkan Informasi Salah Konsepsi dalam Aljabar (Doctoral dissertation, UNY).

Kusaeri, K. (2017). Terbentuknya Konsepsi Matematika pada Diri Anak dari Perspektif Teori Reifikasi dan APOS. Jurnal Pendidikan Matematika, 1, 101-105.

Lailiyah, S. (2015). Karakterisasi Penstrukturan Pada Penalaran Analogi Siswa dalam Menyelesaikan Masalah Matematika. Disertasi tidak diterbitkan. Malang: Universitas Negeri Malang.

Lunenburg, F. C. (2012). Teacher's Use of Theoretical Frames for Instructional Planning: Information Processing Theories. Journal of Mathematical Sciences and Mathematics Education. 3(1), 114.

Murdiono, M. (2010). Peningkatan Keterampilan Kewarganegaraan (Civic Skills) Melalui Penerapan Strategi Pembelajaran Berbasis Masalah, Jurnal Penelitian Ilmu Pendidikan, 3(1), 16-29. 
Mitchelmore, M. C. \& White, P. (2004). Abstraction in Mathematics and Mathematics Learning. Artikel dimuat dalam Proceedings of The $28^{\text {th }}$ Conference of The International Group for the Psychology of Mathematics Education, 3, 329-336.

Nayazik, A. \& Sukestiyarno (2012). Pembelajaran Matematika Model Ideal Problem Solving dengan Teori Pemrosesan Informasi untuk Pembentukan Pendidikan Karakter dan Pemecahan Masalah Materi Dimensi Tiga Kelas X SMA, Phytagoras, 7(2), 1-8.

Ngilawajan, D. A. (2013). Proses Berpikir Siswa SMA dalam Memecahkan Masalah Matematika Materi Turunan Ditinjau dari Gaya Kognitif Field Independent dan Field Dependent, Pedagogia, 2(1), 71-83.

Panjaitan, B. (2013). Proses Kognitif Siswa dalam Pemecahan Masalah Matematika, Jurnal Ilmu Pendidikan, 19(1), 17-25.

Putra, D. B. P.dkk. (2017). Proses Berpikir Mahasiswa Teknik Informatika dalam Menyelesaikan Statistika Berdasarkan Teori Pemrosesan Informasi. Jombang: Universitas Hasyim Asy'ari.

Rehalat, A. (2014). Model Pembelajaran Pemrosesan Informasi, Jurnal Pendidikan Ilmu Sosial, 23(2), $1-10$.

Riyadi, S. (2011). Pemrosesan Informasi dalam Belajar Gerak, Jurnal Ilmiah SPIRIT, 11 (2), 1-12.

Rohana, R. (2015). Peningkatan Kemampuan Penalaran Matematis Mahasiswa Calon Guru Melalui Pembelajaran Reflektif, Infinity Journal, 4(1), 105-119.

Ruggiero, V. R. (2011). Beyond Feelings: A guide to Critical Thinking. New York: Mc Graw Hill.

Slavin, R.E. (2009). Educational Psychology: Theory and Practice $\left(9^{\text {th }}\right.$ ed.). Boston: Allyn and Bacon.

Soedjadi, R. (2000). Kiat Pendidikan Matematika di Indonesia; Konstatasi Keadaan Masa Kini Menuju Harapan Masa Depan. Jakarta: Direktorat Jenderal Pendidikan Tinggi Departemen Pendidikan Nasional.

Solso, R. L., Maclin, O.H. \& Maclin, M.K. (2008). Psikologi Kognitif. Jakarta: Erlangga.

Sternberg, R.J. (2006). Cognitive Psychology ( $4^{\text {th }}$ ed.). Belmont, CA: Thompson Wadsworth.

Supriadi, D., Mardiyana, M, \& Subanti, S. (2015). Analisis Proses Berpikir Siswa dalam Memecahkan Masalah Matematika Berdasarkan Langkah Polya Ditinjau Dari Kecerdasan Emosional Siswa Kelas VIII SMP Al Azhar Syifa Budi Tahun Pelajaran 2013/2014. Jurnal Elektronik Pembelajaran Matematika, 3(2), 204-214.

Van De Walle, J.A. (2008). Matematika Sekolah Dasar dan Menengah: Pengembangan Pengajaran. Jakarta: Gramedia.

Woolfolk, A. (2008). Educational Psychology (10 $0^{\text {th }}$ ed.). Boston, MA: Allyn \& Bacon.

Zaslavsky, O. (2008). Meeting the challenges of mathematics teacher education through design and use of tasks that facilitate teacher learning. In B. Jaworski and T. Wood (eds), The Mathematics Teacher Educator as a Developing Professional (pp 93-114). Rotterdam, Netherlands: Sense Publishers. 